s. Research Square

\title{
Evaluation of DNA integrity and mitochondrial membrane potential in catfish Pseudoplatystoma magdaleniatum, induced by exposure to different concentrations of ibuprofen
}

Sara E. Gallego Ríos ( $\nabla$ sara.gallego@udea.edu.co)

Universidad de Antioquía https://orcid.org/0000-0002-5143-1869

Gustavo A. Peñuela

Universidad de Antioquia

\section{Research Article}

Keywords: Fish, Flow cytometry, Blood, ADN, Mitochondrial membrane potential, Ibuprofen

Posted Date: June 28th, 2021

DOI: https://doi.org/10.21203/rs.3.rs-577858/v1

License: (a) (i) This work is licensed under a Creative Commons Attribution 4.0 International License. Read Full License 


\section{Abstract}

There are few studies to date that determine the effects of ibuprofen on mitochondrial membrane potential $(\triangle \Psi \mathrm{M})$ and DNA integrity in neotropical fish. The objective of this study is to determine if four months' exposure to ibuprofen in different concentrations ( 25 and $50 \mu \mathrm{g} / \mathrm{L}$ ) produces effects on $\triangle \Psi \mathrm{M}$ and alters the integrity of DNA in striped catfish Pseudoplatystoma magdaleniatum. For this study, the fish were placed in tanks with water at constant concentrations of 0 (control), 25, and $50 \mu \mathrm{g} / \mathrm{L}$ of ibuprofen for four months. Subsequently, blood samples were taken for analysis of $\triangle \Psi \mathrm{M}$ and DNA integrity, using a flow cytometer LSRFortessa BD Biosciences. After four months of exposure to ibuprofen at different concentrations, the results showed no increase in Low $\triangle \Psi \mathrm{M}$, indicating that there are no alterations in the mitochondrial membrane potential. On the other hand, the percentages of DNA damage were below 0.39 , which indicates that there were no alterations in DNA integrity. It is possible that under the conditions in which this study was conducted (ibuprofen levels, exposure time), they are not sufficient to demonstrate the effects caused by this drug. Higher ibuprofen levels and/or longer exposures may be required to determine alteration in $\triangle \Psi \mathrm{M}$ and DNA integrity. Flow cytometric analysis for these types of samples is a fast, specific, and reliable technique, compared to traditional methods.

\section{Introduction}

Pharmaceuticals are all prescription or over-the-counter drugs, as well as veterinary therapeutic drugs, for the treatment of both human and animal diseases. On the other hand, personal care products $(P C P)$ are used to improve the quality of daily life. In recent years, concern has increased about the presence of PPCPs (Pharmaceutical and Personal Care Products) in the different compartments of the aquatic environment, such as water, sediments, and biota, in concentrations that are capable of generating harmful effects for both aquatic animals and humans; becoming a major concern, as PPCPs has tended to increase in human and veterinary medicine, leading to a steady release to the environment (Petrie et al. 2014; Aristizabal-Ciro et al. 2017; Ebele et al. 2017; Pico et al. 2019).

Contamination with PPCPs in water can occur by different routes: the first is the absorption of PPCPs by the body after use, followed by excretion and release into the sewage system or septic tank (Dey et al. 2019). After incomplete wastewater treatment, these waters can be used as biosolids, applied as fertilizers on agricultural lands, in addition to leaching processes, PPCPs can reach groundwater (Kim et al. 2009; Petrie et al. 2014; Dey et al. 2019; White et al. 2019); these PPCPs can also reach freshwater through runoff from the soil treated with these biosolids. The second way is through its manufacture since the wastewater from these production factories goes directly to the WWTP. In addition, PPCPs can be discharged through shower, bath, sink, and swimming wastes (Archer et al. 2017; Ebele et al. 2017). Most of these compounds and their metabolites are biologically active (Sathishkumar et al. 2020) and can cause alterations in aquatic organisms exposed for long periods, causing endocrine alterations, genotoxicity, carcinogenicity, and fetal malformations, among others (Giang et al. 2019; Liu et al. 2020)

Ibuprofen is a non-steroidal anti-inflammatory drug (NSAID), this drug reversibly inhibits the synthesis of prostanoids (prostaglandins, prostacyclins, and thromboxanes) (González-Mira et al. 2016), by non-selectively inhibiting cyclooxygenase 1 and 2 enzymes and blocking the synthesis of prostaglandins and thromboxanes (Motov et al. 2020); Ibuprofen interferes with the cyclooxygenase pathway, decreasing the catalysis of prostaglandin biosynthesis from arachidonic acid (Parolini 2020). This drug can cause alterations in 
reproduction and development (Xia et al. 2017), oxidative stress, hematological changes, and DNA damage in fish (Mathias et al. 2018).

Among aquatic organisms, fish is an excellent tool for the analysis of possible genotoxic alterations, due to their ability to metabolize, concentrate and store water-borne pollutants (Ternjej et al. 2010). The striped catfish Pseudoplatystoma magdaleniatum is an endemic species and the second most commercially important in the Colombian fishery. However, it is among the critically endangered species (Mojica et al. 2012), mainly due to habitat degradation, embalming of rivers, overfishing, deforestation, and organic and inorganic contamination (Mojica et al. 2016; Herrera-Cruz et al. 2019). This fish inhabits the Magdalena and Cauca basins, the main rivers of Colombia; historically, these basins have presented unsolved environmental problems, derived from deforestation, erosion, and contamination by solid and liquid waste (Galvis and Mojica 2007; Noreña-Ramirez et al. 2012; Zapata et al. 2015; Tejeda-Benítez et al. 2018). This threatens both the economy of the communities where the catfish live, where it is a main source of work, income, and food security as a source of food (FriedrichEbert-Stiftung and Foro Nacional Ambiental 2015). In addition, catfish, being at the top of the food chain, indirectly contributes to the control and regulation of the aquatic system where it lives.

The Magdalena basin, made up of the Cauca and Magdalena rivers, the main rivers of Colombia, is the main recipient of domestic wastewater, water contaminated with pesticides used in crops, illegal gold extraction, and discharges from industries such as oil refining and tanneries (Tejeda-Benítez et al. 2018). The investigations in the Magdalena basin have been carried out mainly in the analysis of heavy metals, leaving aside the investigations for the determination of some pollutants such as pharmaceutical products in the Magdalena and Cauca rivers (Noreña-Ramirez et al. 2012; Tejeda-Benitez et al. 2016; Tejeda-Benítez et al. 2018). The main source of contamination in the Magdalena and Cauca rivers is wastewater from the main cities Bogotá, Medellín, Cali, and Barranquilla (Galvis and Mojica 2007; Tejeda-Benitez et al. 2016). In the main cities of the country, some investigations have been carried out on the content of PPCPs in the waters, finding that the greatest contribution of pharmaceutical products is non-steroidal anti-inflammatory drugs, anticonvulsants, and antibiotics (Gracia-Lor et al. 2012; Hernández et al. 2015; Aristizabal-Ciro et al. 2017; Bedoya-Ríos et al. 2018; Arias 2019; Pemberthy et al. 2020).

Ibuprofen is considered a ubiquitous pollutant as it has been found in tributaries and effluents from wastewater treatment plants, surface waters, drinking water, sludge, and hospital effluents; Ibuprofen concentrations have been reported worldwide in the range of 0.001 and $75.8 \mu \mathrm{g} / \mathrm{L}$ (Gutiérrez-Noya et al. 2020) Therefore, it is possible that ibuprofen is present in the Magdalena river basin, causing alterations in the catfish that inhabit these areas and being one of the possible causes of its decrease in the basin. The determination of possible genotoxic alterations, such as mitochondrial membrane potential $(\triangle \Psi M)$ and DNA integrity can be determined by blood cells, which are constantly exposed to reactive oxygen species and provide a relatively non-invasive source for the biomonitoring, also the sampling is done relatively easily and the fish can be returned to the water after collection without having to sacrifice them to carry out the study (Ternjej et al. 2010). The analyzes can be carried out using flow cytometry, since it is a fast and reliable technique to quantify and characterize some cell populations, allowing the evaluation of immunopathological processes in fish (Alzamora-Gonzales et al. 2015).

The $\triangle \Psi \mathrm{M}$ is generated by proton pumps (Complexes I, III, and IV), it is an indispensable component in the energy storage process during oxidative phosphorylation. The $\Delta \Psi M$ together with the proton gradient forms the transmembrane potential of hydrogen ions that are used to produce ATP, resulting from the redox

Page $3 / 20$ 
transformations associated with the activity of the Krebs cycle. A prolonged decrease or increase in normal levels of $\Delta \Psi_{\mathrm{m}}$ can induce a loss of cell viability and be a cause of various alterations (Zorova et al. 2018).

Another parameter that can be measured by flow cytometry is the integrity of the DNA. The determination of both parameters is possible by the use of different stains; DiOC6 (3,3'-dihexyloxacarbocyanine iodide), is a fluorescent dye, its function is to stain the endoplasmic reticulum of a cell, membranes of vesicles, and mitochondria, the union is possible through the hydrophilic groups of the dye (Rieger et al. 2011). On the other hand, propidium iodide (PI) is used to determine if cells are viable, underwent apoptosis or necrosis, through differences in the integrity of the plasma membrane and permeability. This dye is one of the most used since it is inexpensive, stable, and is a good indicator since it can exclude living cells. PI binds to double-stranded DNA by intercalation between base pairs. The ability of PI to enter a cell depends on the permeability of the membrane. In late apoptotic and necrotic cells, plasma and nuclear integrity decrease, allowing PI to pass through the membranes, interspersing with nucleic acids (Özgen et al. 2000; Rieger et al. 2011).

Given that ibuprofen is one of the most consumed drugs in the world ((Ngo and Bajaj 2020) and so far there is no information on the possible alterations in mitochondrial membrane potential and DNA integrity caused by ibuprofen in Neotropical fish such as Pseudoplatystoma magdaleniatum, it is necessary to determine if ibuprofen at different doses $(0,25,50 \mu \mathrm{g} / \mathrm{L})$ exposed for four months to $P$. magdaleniatum produces genotoxic alterations, determined by flow cytometry, is one of the possible causes of its decline.

\section{Materials And Methods 2.1. Fish Husbandry}

The striped catfish Pseudoplatystoma magdaleniatum (Siluriformes: Pimelodidae) presents sexual dimorphism, reproductive migrations with temporality for spawning (Arce et al. 2014), and not possessing scales. The catfish is nocturnal, feeds on fish, some arthropods, and seeds (Santamaría Merchán 2013).

These species were caught with the authorizations required by current regulations, Framework Permit issued by the Autoridad Colombiana de Licencias Ambientales (ANLA) in Resolution 1461 of December 3, 2014. The number of samples was determined based on the considerations of the Ethics Committee for Animal Experimentation of the Universidad de Antioquia, with Act 89 of May 29, 2014, in which the minimum use of fish is recommended for the extraction, to minimize the impact on the capture of these fish, which have been devastated in the last decades. All animal experiments were by Directive 2010/63/EU of the European Parliament (Official Journal of the European Union 2010).

All the fish were caught in the Cauca River. Sexually mature striped catfish were used. For the experimentation, six individuals were arranged per experimental unit, separated into males and females with average weights and lengths of $1.86 \pm 0.49 \mathrm{~kg}$ and $61.14 \pm 4.76 \mathrm{~cm}$ for males and $2.07 \pm 0.64 \mathrm{~kg}$ and $63.86 \pm 6.01 \mathrm{~cm}$ for females. The experimental units were divided into 3 control groups 0,25 , and $50 \mu \mathrm{g} / \mathrm{L}$. Due to photochemical degradation and fish uptake of ibuprofen, ibuprofen (1335508 USP, Rockville, USA) concentrations were readjusted in each tank. Concentrations ranged from $17.8-27.9 \mu \mathrm{g} / \mathrm{L}(25 \mu \mathrm{g} / \mathrm{L})$ to $41.7-52.2 \mu \mathrm{g} / \mathrm{L}(50 \mu \mathrm{g} / \mathrm{L})$, and the control group always remained below the limit of quantification, Table 1. All experimentation was carried out at the Fish Culture Research Institute of the University of Córdoba (CINPIC) located in Montería, in the department of 
Córdoba. The fish were acclimatized for two months in tanks of $3250 \mathrm{~m}^{3}$, with a 12/12 photoperiod throughout the year.

Table 1

Water analysis of the experimentation tanks carried out by UHPLCQqQ-MS/MS.

\begin{tabular}{|llll|}
\hline Time & Tanks & & \\
\cline { 2 - 4 } & $\mathbf{0} \mu \mathrm{g} / \mathrm{L}(<\mathrm{LOQ})$ & $25 \mu \mathrm{g} / \mathrm{L}$ & $50 \mu \mathrm{g} / \mathrm{L}$ \\
\hline Day 1 & $0.308 \pm 0.016$ & $20.583 \pm 0.354$ & $49.811 \pm 0.898$ \\
\hline Day 3 & $0.066 \pm 0.018$ & $27.296 \pm 0.117$ & $46.182 \pm 2.459$ \\
\hline Day 5 & $0.177 \pm 0.206$ & $21.094 \pm 0.244$ & $51.468 \pm 1.584$ \\
\hline Week 2 & $0.251 \pm 0.159$ & $22.052 \pm 0.523$ & $41.706 \pm 1.757$ \\
\hline Week 3 & $0.285 \pm 0.122$ & $24.959 \pm 0.824$ & $52.223 \pm 0.637$ \\
\hline Week 4 & $0.366 \pm 0.064$ & $22.952 \pm 0.822$ & $43.712 \pm 0.669$ \\
\hline Week 5 & $0.305 \pm 0.175$ & $17.777 \pm 0.732$ & $42.106 \pm 1.911$ \\
\hline Week 6 & $0.172 \pm 0.047$ & $27.713 \pm 0.706$ & $50.201 \pm 2.618$ \\
\hline Week 7 & $0.185 \pm 0.136$ & $23.244 \pm 0.144$ & $44.141 \pm 0.315$ \\
\hline Week 8 & $0.253 \pm 0.296$ & $27.909 \pm 4.099$ & $50.623 \pm 0.721$ \\
\hline Week 9 & $0.471 \pm 0.002$ & $24.631 \pm 1.892$ & $45.749 \pm 0.693$ \\
\hline Week 10 & $0.352 \pm 0.069$ & $26.703 \pm 0.973$ & $51.390 \pm 2.026$ \\
\hline Week 11 & $0.183 \pm 0.015$ & $23.907 \pm 0.640$ & $45.403 \pm 2.232$ \\
\hline Week 12 & $0.211 \pm 0.181$ & $18.591 \pm 1.579$ & $43.530 \pm 0.256$ \\
\hline Week 13 & $0.456 \pm 0.059$ & $25.665 \pm 0.904$ & $49.794 \pm 0.431$ \\
\hline Week 14 & $0.267 \pm 0.141$ & $23.565 \pm 1.014$ & $48.483 \pm 0.069$ \\
\hline Week 15 & $0.185 \pm 0.021$ & $21.866 \pm 0.513$ & $47.077 \pm 0.519$ \\
\hline Week 16 & $0.287 \pm 0.185$ & $26.858 \pm 0.792$ & $51.076 \pm 1.064$ \\
\hline Week 17 & $0.304 \pm 0.001$ & $0.413 \pm 0.121$ & $0.376 \pm 0.026$ \\
\hline LOQ = limit of quantification $(0.500 \mu \mathrm{g} / \mathrm{L})$. & \\
\hline
\end{tabular}

The fish were fed with live feed Astyanax sp (ad libitum), grown at the Fish Culture Research Institute. As described in Table 2, the quality of the water in the tanks increased; Parameters related to water quality and optimal conditions for fish maintenance were measured weekly, a portable multiparameter $(\mathrm{HACH}, \mathrm{Sension}+$ MM15, USA) was used to determine dissolved oxygen, temperature, $\mathrm{pH}$ and saturation percentage of oxygen. Total alkalinity, total hardness, and volatile solids and fixed solids were determined according to Standard 
Methods 2320 (Rice et al. 2017a), 2340 C (Rice et al. 2017b), and 2540 E(Rice et al. 2017c), respectively. Ammonia nitrogen and ammonia were measured using a kit (API, USA).

Table 2

Water quality of the experimental units.

\begin{tabular}{|c|c|c|c|c|c|c|c|}
\hline Month & $\begin{array}{l}\text { Temperature } \\
\left({ }^{\circ} \mathrm{C}\right)\end{array}$ & $\begin{array}{l}\text { Oxygen } \\
\text { saturation } \\
(\%)\end{array}$ & $\mathrm{pH}$ & $\begin{array}{l}\text { Ammonium } \\
\left(\mathrm{NH}_{3} / \mathrm{NH}_{4}^{+}\right)\end{array}$ & $\begin{array}{l}\text { Total } \\
\text { alkalinity } \\
(\mathrm{mg} / \mathrm{L} \mathrm{CaCO})\end{array}$ & $\begin{array}{l}\text { Total } \\
\text { hardness } \\
\left(\mathrm{mg} / \mathrm{LaCO}_{3}\right)\end{array}$ & $\begin{array}{l}\text { Fixed } \\
\text { solids } \\
\text { (mg/L) }\end{array}$ \\
\hline 1 & $29.31 \pm 0.89$ & $\begin{array}{l}86.36 \pm \\
3.89\end{array}$ & $\begin{array}{l}7.60 \\
\pm \\
0.00\end{array}$ & $0.35 \pm 0.14$ & $64.95 \pm 4.88$ & $67.57 \pm 3.21$ & $\begin{array}{l}208.5 \pm \\
2.12\end{array}$ \\
\hline 2 & $28.54 \pm 0.38$ & $\begin{array}{l}91.85 \pm \\
4.25\end{array}$ & $\begin{array}{l}7.83 \\
\pm \\
0.20\end{array}$ & $0.42 \pm 0.30$ & $68.30 \pm 3.68$ & $72.78 \pm 6.16$ & $\begin{array}{l}213 \pm \\
9.90\end{array}$ \\
\hline 3 & $28.55 \pm 0.36$ & $\begin{array}{l}89.31 \pm \\
5.89\end{array}$ & $\begin{array}{l}7.93 \\
\pm \\
0.21\end{array}$ & $0.46 \pm 0.29$ & $69.95 \pm 5.59$ & $77.26 \pm 1.48$ & $\begin{array}{l}214 \pm \\
1.41\end{array}$ \\
\hline 4 & $28.98 \pm 0.43$ & $\begin{array}{l}91.06 \pm \\
2.33\end{array}$ & $\begin{array}{l}7.80 \\
\pm \\
0.00\end{array}$ & $0.42 \pm 0.13$ & $67.55 \pm 5.30$ & $75.60 \pm 6.14$ & $\begin{array}{l}212 \pm \\
5.66\end{array}$ \\
\hline \multicolumn{8}{|c|}{ Values are expressed as mean \pm SD. } \\
\hline
\end{tabular}

\subsection{Experimental design}

The fish caught for the experimentation are fish of sexual maturity size. The experiment lasted four continuous months, the time necessary for this species to develop its gametes (Palacio 2009; Arce et al. 2014). The experimentation was carried out with three independent experiments, in separate tanks, the fish were divided into three groups according to their exposure: 0 control, 25 and $50 \mu \mathrm{g} / \mathrm{L}$, the control group $(0 \mu \mathrm{g} / \mathrm{L})$. Due to the photochemical degradation and absorption of ibuprofen by the fish, $50 \%$ of the water in the tanks was replaced weekly and the ibuprofen concentrations were readjusted in each tank. Water samples were taken in amber glass containers, kept at $4-6^{\circ} \mathrm{C}$ before being analyzed (maximum time 24 hours). Ibuprofen was quantified using an ultra-high-performance liquid chromatography coupled with triple quadrupole mass spectrometry (UHPLC-QqQMS/MS) following the modified EPA method 1694 (Environmental Protection Agency (EPA) et al. 2007) (modification of the volume of conditioning and elution, as well as the conditions of the equipment).

The concentrations of ibuprofen added were selected taking into account environmental concentrations present in the tributaries $(<0.984-6.328 \mu \mathrm{g} / \mathrm{L})$ and effluents $(<0.065-0.491 \mu \mathrm{g} / \mathrm{L})$ of wastewater treatment plants (Kasprzyk-Hordern et al. 2009) and some rivers in the United Kingdom (1.681-33.764 $\mu \mathrm{g} / \mathrm{L}$ (Petrie et al. 2014)). As well as sublethal treatment (1/10 of LC 50) of some similar species was $14.2 \mathrm{mg} / \mathrm{L}$ (Saravanan et al. 2012). Taking into account the ibuprofen levels in the water and an estimate of the sublethal dose, a concentration of $25 \mu \mathrm{g} / \mathrm{L}$ and $50 \mu \mathrm{g} / \mathrm{L}$ was selected to evaluate the possible effects on mitochondrial membrane potential and DNA integrity.

\subsection{Blood Sampling}


Blood samples were taken 14 days after the addition of ibuprofen and after four months. Blood samples were collected by a direct puncture in the tail vein with the help of a vacutainer; the tubes in which the samples were collected contained EDTA K2 anticoagulants. Blood samples were taken for each treatment and all samples were processed separately. Blood was drawn from each fish and kept for 1 hour at $4-6^{\circ} \mathrm{C}$ and in the absence of ultraviolet light until reaching the laboratory for analysis. Whole blood was used for all analyzes, as blood is an excellent source of DNA. The analyzes are carried out with white blood cells (leukocytes) and not red blood cells (erythrocytes) since they lack a nucleus.

\subsection{Determination of Mitochondrial Membrane Potential $(\Delta \Psi \mathrm{M})$}

For the determination of $\triangle \Psi \mathrm{M}$ in the blood samples, 3,3'-dihexyloxacarbocyanine iodide (DiOC 6 , Molecular Probes by Life Technologies, Thermo Fisher Scientific) was used, this analysis was evaluated with an adapted version of the protocol described by Zamzami et al. (1996). This fluorescent dye is used for mitochondrial staining under the influence of the permeability transition (Rojas et al. 2000; Rieger et al. 2011). For analysis, a polystyrene tube was used to deposit the DiOC6, a phosphate buffer (PBS) at a final concentration of $800 \mathrm{nM}$ and $10 \mu \mathrm{L}$ of blood. Subsequently, to stain the cells and simultaneously assess their viability, a final concentration of $1 \mathrm{mg} / \mathrm{mL}$ of propidium iodide (PI, Thermo Fisher Scientific) was added.

Samples were incubated for 30 minutes and $\triangle \Psi M$ was measured by flow cytometry (LSRFortessa, BD Biosciences). Subsequently, it was separated in three ways according to the intensity of DIOC6 in the Moflo XDP using a $70 \mu \mathrm{m}$ nozzle, at a frequency of 100 thousand $\mathrm{Hz}$, with a minimum efficiency of 98 for each of the three forms of separation. The temporal analysis was carried out in the high uptake and intermediate uptake cells of $\mathrm{DIOC}_{6}$, Fig. 1. The mitochondrial membrane potential was determined at the levels, low, medium, and high $\triangle \Psi \mathrm{M}$. Flow cytometry data were analyzed using FlowJo software version 10.6.2 (Tree Star Inc., Ashland, Oregon, United States).

\subsection{Determination of DNA Integrity}

DNA integrity was evaluated by PI staining. Cells were fixed with $300 \mu \mathrm{L}$ of $70 \%$ ethanol (Merck, Germany) prepared in PBS ( $\mathrm{pH} 7.4)$ for 12 hours at $4^{\circ} \mathrm{C}$. The samples were centrifuged $\left(500 \mathrm{~g}, 5\right.$ minutes, $\left.4^{\circ} \mathrm{C}\right)$ and the resulting granules were washed twice with $3.0 \mathrm{~mL}$ of PBS. Cells were stained with PI $1 \mu \mathrm{g} / \mathrm{mL}$ in PBS with $0.37 \%$ w/v EDTA, $0.01 \%$ v/v of Triton X-100 and $200 \mathrm{U} / \mathrm{mL}$ of RNase A (Sigma-Aldrich). The samples were incubated for 30 minutes and DNA integrity was measured by flow cytometry (LSRFortessa, BD Biosciences) (Restrepo et al. 2019).

\subsection{Analysis of Flow Cytometry}

The determination of mitochondrial membrane damage was performed by excluding aggregates by selecting the cell population of interest after contrasting the size (FSH) and granularity (SSC) to select unique events. After performing this exclusion, $\mathrm{DiOC}_{6}$-positive cells were compared with propidium iodide (PI)-negative cells, differentiating between the populations of erythrocytes and leukocytes, Fig. 2.

For the determination of DNA integrity, an exclusion of aggregates was also performed by selecting the cell population of interest after contrasting the size (FSH) and granularity (SSC), to select the unique events. Once the unique events were selected, employing PI-A and PI-W, the single cells were selected to determine the DNA integrity employing the histogram, Fig. 3. 


\subsection{Statistical Analysis}

Statistical analysis was performed using Statgraphics Centurion XVII (StatPoint Inc., USA). The evaluation of the normality of the continuous variables was performed via the Shapiro-Wilk test. An analysis of variance (ANOVA) was used to evaluate the existence of significant differences between $\triangle \Psi M$ and DNA integrity. If this gave a statistically significant difference, a post-ANOVA by the least significant difference test (LSD-Fisher) was used. Statistical differences for $\mathrm{PI}+$ and $\triangle \Psi \mathrm{M}$ were analyzed by two-way analysis of variance (ANOVA) with exposure time, concentration, and "time $x$ concentration" interaction as variables. For all statistical analyzes, the significance criterion was established at $p<0.05$.

\section{Results And Discussion}

Studies carried out in fish have shown that the ibuprofen present in the waters can cause an increase in the activity of glutathione-S-transferase in the kidney, reduced glutathione peroxidase activity, decreased white blood cell count, causing nephrotoxicity and immunosuppressive effect (Mathias et al. 2018), increased cardiac output in embryos, decreased blood cells density (Zhang et al. 2019), and a significant reduction in the hatching rate (Xia et al. 2017). So far, no publications have been found on the possible alterations on the integrity of the DNA in $P$. magdaleniatum caused by the presence of ibuprofen in the waters.

An analysis of $\triangle \Psi M$ was performed, as an indicator of cell viability. This analyzed parameter reflects the pumping of hydrogen through the inner membrane in the processes of electron transport and oxidative phosphorylation. These processes are necessary for the production of ATP, which means that mitochondrial dysfunction is closely related to an alteration in the membrane potential that would cause a decrease in the production of ATP (Padmini and Usha Rani 2011).

We analyzed the variations between the $\triangle \Psi \mathrm{M}$ and cells with damage to the cell membrane, positive for $\mathrm{PI}$. Table 3 shows the results for a two-way analysis of variance (ANOVA), where it is observed that there is no statistically significant difference in the $\mathrm{PI}+$ samples between the different treatments, nor in the comparisons concerning the four months of exposure. For the $\triangle \Psi \mathrm{M}$ there is no statistically significant difference between the High $\triangle \Psi \mathrm{M}$, however, comparing the $\triangle \Psi \mathrm{M}$ between the treatments and after exposure, the Medium $\triangle \Psi \mathrm{M}$ presents statistically significant differences $(p<0.05)$ with an increase in the percentage after four months of treatment, as well as a decrease in the percentages of Low $\triangle \Psi M$ after four months of exposure to ibuprofen. Despite this difference between Medium and Low $\triangle \Psi \mathrm{M}$, there was no decrease in $\triangle \Psi \mathrm{M}$ after four months of treatment with ibuprofen. It is difficult to make comparisons with other research since there is not much literature on this type of analysis in tropical fish and it could be inferred that this drug does not produce loss of mitochondrial function in the concentrations in which the experiment is carried out. 
Table 3

Variations in mitochondrial membrane potential $(\triangle \Psi \mathrm{M})$ and $\mathrm{Pl}+$, concerning exposure time and concentrations of ibuprofen to which P. magdaleniatum were exposed.

\begin{tabular}{|llll|}
\hline Parameter & \multicolumn{3}{l|}{ Source of variation } \\
\cline { 2 - 4 } & Time & Concentration & Interactions \\
& p-value & p-value & p-value \\
\hline $\mathrm{PI}+$ & 0.96 & 0.32 & 0.79 \\
\hline High $\triangle \Psi \mathrm{M}$ & 0.93 & 0.83 & 0.23 \\
\hline Medium $\triangle \Psi \mathrm{M}$ & $0.001 *$ & 0.43 & 0.36 \\
\hline Low $\triangle \Psi \mathrm{M}$ & $0.01 *$ & 0.54 & 0.43 \\
\hline $\mathrm{p}<0.05$, ANOVA for exposure time and concentration. \\
\hline *Significant factor.
\end{tabular}

Table 4 shows the analysis of $\triangle \Psi \mathrm{M}$, the median fluorescence intensity, determined by sex and ibuprofen concentration in the different analysis times. For females exposed to $25 \mu \mathrm{g} / \mathrm{L}$ of ibuprofen and presenting ratios 0.75 and 0.76 (High $\triangle \Psi \mathrm{M}$ and Medium $\triangle \Psi \mathrm{M}$, respectively), it is indicated that at the time of the assay their leukocytes had a less mitochondrial function at time zero. However, females exposed to $50 \mu \mathrm{g} / \mathrm{L}$ and presenting a ratio of 1.63 had mitochondrial hyperactivity at time zero. Both events are due to a type of stress that can be interpreted respectively as depolarization and hyperpolarization. Meanwhile, the analyses performed after four months of exposure to this ibuprofen show, for males exposed to a concentration of $50 \mu \mathrm{g} / \mathrm{L}$ with ratios of 0.68 and 0.70 (High $\triangle \Psi M$ and Medium $\triangle \Psi$ M, respectively), that $32 \%$ and $30 \%$ of their leukocytes present lower DIOC $_{6}$ uptake than the control at the time of the test. For those that have a ratio above 1 (High $\Delta \Psi \mathrm{M}$ ), there are 12,28 , and $34 \%$ of leukocytes with some hyperpolarization and, as these do not exceed 1.5 , this may be due to the fluctuations of the test. 
Table 4

Percentage of mitochondrial membrane potential $(\triangle \Psi \mathrm{M})$, median fluorescence intensity, and ratio, related by sex and ibuprofen concentration in the different analysis times applied to $P$. magdaleniatum.

\begin{tabular}{|c|c|c|c|c|c|c|c|c|c|c|}
\hline \multirow[t]{3}{*}{ Sex } & \multirow{2}{*}{$\begin{array}{l}\text { Concentration } \\
(\mu \mathrm{g} / \mathrm{L})\end{array}$} & \multicolumn{9}{|c|}{ Time zero } \\
\hline & & $\begin{array}{l}\text { High } \\
\triangle \Psi M \\
(\%)\end{array}$ & $\begin{array}{l}\text { MFI } \\
\text { High }\end{array}$ & Ratio & $\begin{array}{l}\text { Medium } \\
\triangle \Psi M \\
(\%)\end{array}$ & $\begin{array}{l}\text { MFI } \\
\text { Medium }\end{array}$ & Ratio & $\begin{array}{l}\text { Low } \\
\triangle \Psi \mathrm{M} \\
(\%)\end{array}$ & $\begin{array}{l}\text { MFI } \\
\text { Low }\end{array}$ & Ratio \\
\hline & 0 control & $\begin{array}{l}12.0 \\
\pm 4.8 \\
a b\end{array}$ & 3561 & 1.00 & $\begin{array}{l}30.0 \pm \\
6.2^{\mathrm{ab}}\end{array}$ & 1972 & 1.00 & $\begin{array}{l}2.9 \\
\pm 3.7 \\
a b\end{array}$ & 1076 & 1.00 \\
\hline Female & 25 & $\begin{array}{l}9.1 \\
\pm 2.9 \\
a\end{array}$ & 3352 & 0.76 & $\begin{array}{l}22.6 \pm \\
5.9^{a}\end{array}$ & 2210 & 0.75 & $\begin{array}{l}1.1 \\
\pm 1.0 \\
a\end{array}$ & 568 & 0.36 \\
\hline Male & & $\begin{array}{l}10.9 \\
\pm 1.0 \\
a b\end{array}$ & 3547 & 0.91 & $\begin{array}{l}32.9 \pm \\
7.3^{\mathrm{ab}}\end{array}$ & 1957 & 1.10 & $\begin{array}{l}1.2 \\
\pm 0.8 \\
b\end{array}$ & 1154 & 0.42 \\
\hline Female & 50 & $\begin{array}{l}19.6 \\
\pm \\
12.4 \\
b\end{array}$ & 3613 & 1.63 & $\begin{array}{l}17.8 \pm \\
3.3^{a}\end{array}$ & 2250.5 & 0.59 & $\begin{array}{l}0.5 \\
\pm 0.2 \\
a\end{array}$ & 525.5 & 0.00 \\
\hline Male & & $\begin{array}{l}13.1 \\
\pm 6.0 \\
a b\end{array}$ & 3497 & 1.09 & $\begin{array}{l}37.2 \pm \\
7.1^{a b c}\end{array}$ & 1777 & 1.24 & $\begin{array}{l}4.4 \\
\pm 3.6 \\
a b\end{array}$ & 1181 & 1.51 \\
\hline \multirow[t]{3}{*}{ Sex } & Concentration & \multicolumn{9}{|c|}{ Four months } \\
\hline & & $\begin{array}{l}\text { High } \\
\triangle \Psi M \\
(\%)\end{array}$ & $\begin{array}{l}\text { MFI } \\
\text { High }\end{array}$ & Ratio & $\begin{array}{l}\text { Medium } \\
\triangle \Psi \mathrm{M} \\
(\%)\end{array}$ & $\begin{array}{l}\text { MFI } \\
\text { Medium }\end{array}$ & Ratio & $\begin{array}{l}\text { Low } \\
\triangle \Psi \mathrm{M} \\
(\%)\end{array}$ & $\begin{array}{l}\text { MFI } \\
\text { Low }\end{array}$ & Ratio \\
\hline & 0 control & $\begin{array}{l}11.8 \\
\pm 1.6 \\
a b\end{array}$ & 4200 & 1.00 & $\begin{array}{l}75.7 \pm \\
3.1^{\mathrm{d}}\end{array}$ & 2070 & 1.00 & $\begin{array}{l}0.3 \\
\pm 0.4 \\
a\end{array}$ & 686 & 1.00 \\
\hline Female & 25 & $\begin{array}{l}13.2 \\
\pm 4.5 \\
a b\end{array}$ & 3670 & 1.12 & $\begin{array}{l}74.7 \pm \\
3.6^{d}\end{array}$ & 1995 & 0.99 & $\begin{array}{l}0.5 \\
\pm 0.7 \\
a\end{array}$ & 710 & 1.52 \\
\hline Male & & $\begin{array}{l}15.1 \\
\pm 6.0 \\
a b\end{array}$ & 4242 & 1.28 & $\begin{array}{l}73.6 \pm \\
2.9^{\mathrm{d}}\end{array}$ & 2340 & 0.97 & $\begin{array}{l}0.1 \\
\pm 0.1 \\
a\end{array}$ & 523 & 0.26 \\
\hline
\end{tabular}

Mean \pm SD.

High $\triangle \Psi$ M: samples with high mitochondrial membrane potential.

Medium $\triangle \Psi$ M: samples with medium mitochondrial membrane potential.

Low $\triangle \Psi$ M: samples with low mitochondrial membrane potential.

MFI: median fluorescence intensity.

Different lowercase letters in the columns indicate statistically significant differences $(p<0.05)$. 


\begin{tabular}{|c|c|c|c|c|c|c|c|c|c|c|}
\hline Female & 50 & $\begin{array}{l}15.9 \\
\pm \\
11.3 \\
\text { ab }\end{array}$ & 3941 & 1.34 & $\begin{array}{l}69.1 \pm \\
11.4 \mathrm{~cd}\end{array}$ & 2418.5 & 0.91 & $\begin{array}{l}0.0 \\
\pm 0.0 \\
\mathrm{ab}\end{array}$ & 396 & 0.13 \\
\hline Male & & $\begin{array}{l}8.0 \\
\pm 4.8 \\
a\end{array}$ & 4425 & 0.68 & $\begin{array}{l}53.1 \pm \\
37.8^{\mathrm{bcd}}\end{array}$ & 2322 & 0.70 & $\begin{array}{l}0.1 \\
\pm 0.0 \\
\mathrm{a}\end{array}$ & 499 & 0.16 \\
\hline
\end{tabular}

Mean \pm SD.

High $\triangle \Psi$ M: samples with high mitochondrial membrane potential.

Medium $\triangle \Psi$ M: samples with medium mitochondrial membrane potential.

Low $\triangle \Psi \mathrm{M}$ : samples with low mitochondrial membrane potential.

MFI: median fluorescence intensity.

Different lowercase letters in the columns indicate statistically significant differences $(p<0.05)$.

So far, no comparable results have been found where the analysis for $\triangle \Psi \mathrm{M}$ in blood samples is performed by flow cytometry. However, the determination of $\triangle \Psi \mathrm{M}$ by flow cytometry is suggested as a biomarker due to its higher specificity and quick quantitative assessment of the possible risk of exposure to this type of pharmaceutical (Padmini and Usha Rani 2011).

Table 5 shows the integrity of the DNA, the results for time zero and after four months of exposure to ibuprofen, do not present statistically significant difference between the different treatments, and no effect on DNA is evidenced, since, after four months of exposure to ibuprofen, the average for males and females is $92.30 \%$ for $2 n$, which indicates that the vast majority do not present fragmentation in nonfragmented DNA and only $0.32 \%$ have some type of DNA damage. 
Table 5

DNA integrity, related by sex and ibuprofen concentration at different times of experimentation in $P$. magdaleniatum.

\begin{tabular}{|c|c|c|c|c|c|}
\hline \multirow[t]{2}{*}{ Sex } & \multirow[t]{2}{*}{ Concentration $(\mu \mathrm{g} / \mathrm{L})$} & \multicolumn{4}{|l|}{ Time zero } \\
\hline & & $2 n(\%)$ & $4 n(\%)$ & $<2 \mathrm{n}(\%)$ & Linearity \\
\hline & 0 control & $95.300 \pm 1.908$ & $3.880 \pm 1.600$ & $0.310 \pm 0.105$ & $1.972 \pm 0.014$ \\
\hline Female & \multirow[t]{2}{*}{25} & $94.800 \pm 0.700$ & $4.527 \pm 0.583$ & $0.087 \pm 0.064$ & $1.994 \pm 0.004$ \\
\hline Male & & $94.333 \pm 1.950$ & $4.860 \pm 1.669$ & $0.240 \pm 0.225$ & $1.962 \pm 0.019$ \\
\hline Female & \multirow[t]{2}{*}{50} & $95.750 \pm 0.212$ & $3.560 \pm 0.113$ & $0.360 \pm 0.014$ & $1.985 \pm 0.007$ \\
\hline Male & & $95.600 \pm 1.058$ & $3.590 \pm 0.670$ & $0.321 \pm 0.279$ & $1.970 \pm 0.022$ \\
\hline \multirow[t]{3}{*}{ Sex } & \multirow[t]{2}{*}{ Concentration $(\mu \mathrm{g} / \mathrm{L})$} & Four months & & & \\
\hline & & $2 n(\%)$ & $4 \mathrm{n}(\%)$ & $<2 \mathrm{n}(\%)$ & Linearity \\
\hline & 0 control & $91.300 \pm 0.100$ & $6.950 \pm 0.262$ & $0.395 \pm 0.114$ & $1.928 \pm 0.008$ \\
\hline Female & \multirow[t]{2}{*}{25} & $93.233 \pm 2.139$ & $5.093 \pm 2.169$ & $0.301 \pm 0.033$ & $1.927 \pm 0.020$ \\
\hline Male & & $91.567 \pm 1.210$ & $6.540 \pm 0.920$ & $0.317 \pm 0.035$ & $1.930 \pm 0.010$ \\
\hline Female & \multirow[t]{2}{*}{50} & $92.650 \pm 0.778$ & $6.135 \pm 0.573$ & $0.245 \pm 0.078$ & $1.928 \pm 0.008$ \\
\hline Male & & $92.767 \pm 2.250$ & $5.647 \pm 2.358$ & $0.301 \pm 0.092$ & $1.940 \pm 0.022$ \\
\hline \multicolumn{6}{|c|}{ Mean \pm SD. } \\
\hline & & & & & \\
\hline
\end{tabular}

Comparing these results with other studies where DNA integrity is determined by comet assay, ibuprofen alterations were evident in monocytic cells of Hoplias malabaricus, with exposure of 10-1000 ng / mL (Ribas et al. 2014); in Rhamdia quelen with ibuprofen exposure of $66.40 \mathrm{ng} / \mathrm{L}$, where a statistically significant DNA loss was obtained after 5 and 28 days of exposure of 22.74-34.32\% (Rocco et al. 2010); and in Oreochromis niloticus, where exposure to $300 \mathrm{ng} / \mathrm{L}$ ibuprofen caused genotoxic effects in both acute ( $48 \mathrm{~h}$ ) and subchronic (10 days) exposure (Ragugnetti et al. 2011). For the present study carried out by flow cytometry, it is difficult to make comparisons with other analysis techniques, however, it can be pointed out that hypodiploid cells were not observed, nor was there a loss of linearity that could be interpreted as coming from DNA. It is probable that at the concentrations at which the experimentation was carried out, this drug does not cause DNA damage, but because it is an endocrine disruptor, characterized by not following dose-response patterns, it is possible that at lower exposure concentrations it may cause obvious alterations. Therefore, in this study, they could not be demonstrated.

\section{Conclusions}

This study is one of the first to analyze alterations in mitochondrial membrane potential and DNA integrity by flow cytometry in Neotropical fish. The results for the $\Delta \Psi M$ showed a statistically significant difference for the mean $\triangle \Psi \mathrm{M}$ and the low $\Delta \Psi \mathrm{M}$, but without differences between the $\Delta \Psi \mathrm{M}$ after four months of exposure, 
indicating that at these concentrations and exposure times there is no loss of function. mitochondrial, caused by ibuprofen. On the other hand, there were no alterations in the integrity of the DNA, the percentages of DNA without fragmentation were higher than $90 \%$ in all sexes, levels, and exposure times. It is concluded that the catfish Pseudoplatystoma magdaleniatum exposed to ibuprofen at concentrations of $25,50 \mu \mathrm{g} / \mathrm{L}$ for four months, does not produce alterations in the mitochondrial membrane potential or the integrity of the DNA. More research is needed at different levels of ibuprofen concentration and longer exposure times, since, under the conditions of this study, it was not possible to demonstrate the effects caused by ibuprofen were one of the causes of the decline in this species in the Cauca and Magdalena River Basin of Colombia.

\section{Declarations}

Ethics approval and consent to participate: These species were caught with the authorizations required by current regulations, Framework Permit issued by the Autoridad Colombiana de Licencias Ambientales (ANLA) in Resolution 1461 of December 3, 2014. All animal experiments were following Directive 2010/63/EU of the European Parliament and approved by the Ethics Committee for Animal Experimentation of the Universidad de Antioquia, with Act 89 of May 29, 2014.

Consent for publication: Not applicable

Availability of data and materials: The datasets used and/or analysed during the current study are available from the corresponding author on reasonable request.

Competing interests: The authors declare that they have no conflict of interest.

Funding: This study was funded by the Ministry of Science, Technology, and Innovation of Colombia (grant number 111569944244).

Authors' contributions: Sara E. Gallego R, performed activities related to Methodology, Formal Analysis, Investigation, Writing - Original Draft. Gustavo A. Peñuela was involved in the Funding Acquisition, Resources, Conceptualization, Supervision, and Project Administration. All authors contributed to writing the manuscript.

Acknowledgements: To the Ministry of Science, Technology and Innovation of Colombia, for the financing of project code 111569944244, contract FP 44842 No. 223 of 2015. The GDCON group of the University of Antioquia is also thanked for their part in funding the project.

\section{References}

Alzamora-Gonzales L, de Amat-Herbozo C, Colona-Vallejos E, et al (2015) Método rápido para la cuantificación de leucocitos sanguíneos y su utilidad en la evaluación del estado de salud en trucha arcoíris Oncorhynchus mykiss. Lat Am J Aquat Res 43:1019-1023. https://doi.org/10.3856/vol43-issue5-fulltext-22

Arce JW, Alonso JC, Hernández S, Valderram M (2014) Determination of spawning characteristics and fecundity of the the Magdalena Catfish Pseudoplatystoma magdaleniatum. Biota Colomb 15:70-82

Archer E, Petrie B, Kasprzyk-Hordern B, Wolfaardt GM (2017) The fate of pharmaceuticals and personal care products (PPCPs), endocrine disrupting contaminants (EDCs), metabolites and illicit drugs in a WWTW and 
environmental waters. Chemosphere 174:437-446. https://doi.org/10.1016/j.chemosphere.2017.01.101

Arias J (2019) Pharmaceutical and Personal Hygiene Products (PPcPs): A Threat Little Studied in Colombian Waters. Agric Res Technol 22:1-8. https://doi.org/10.19080/ARTOAJ.2019.22.556201

Aristizabal-Ciro C, Botero-Coy AM, López FJ, Peñuela GA (2017) Monitoring pharmaceuticals and personal care products in reservoir water used for drinking water supply. Environ Sci Pollut Res 24:7335-7347.

https://doi.org/10.1007/s11356-016-8253-1

Bedoya-Ríos DF, Lara-Borrero JA, Duque-Pardo V, et al (2018) Study of the occurrence and ecosystem danger of selected endocrine disruptors in the urban water cycle of the city of Bogotá, Colombia. J Environ Sci Heal - Part A Toxic/Hazardous Subst Environ Eng 53:317-325. https://doi.org/10.1080/10934529.2017.1401372

Dey S, Bano F, Malik A (2019) Pharmaceuticals and personal care product (PPCP) contamination-a global discharge inventory. Elsevier Inc.

Ebele AJ, Abou-Elwafa Abdallah M, Harrad S (2017) Pharmaceuticals and personal care products (PPCPs) in the freshwater aquatic environment. Emerg Contam. https://doi.org/10.1016/j.emcon.2016.12.004

Environmental Protection Agency (EPA), Office of Water, Office of Science and Technology, Engineering and Analysis Division (2007) Method 1694: Pharmaceuticals and Personal Care Products in Water, Soil, Sediment, and Biosolids by HPLC/MS/MS. In: US EPA. https://www.epa.gov/sites/production/files/201510/documents/method_1694_2007.pdf

Friedrich-Ebert-Stiftung, Foro Nacional Ambiental (2015) ¿Para dónde va el río Magdalena? Riesgos sociales, ambientales y económicos del proyecto de navegabilidad, First. Bogotá (Colombia)

Galvis G, Mojica JI (2007) The Magdalena River fresh water fishes and fisheries. Aquat Ecosyst Heal Manag 10:127-139. https://doi.org/10.1080/14634980701357640

Giang PT, Burkina V, Sakalli S, et al (2019) Effects of Multi-Component Mixtures from Sewage Treatment Plant Effluent on Common Carp (Cyprinus carpio) under Fully Realistic Condition. Environ Manage 63:466-484. https://doi.org/10.1007/s00267-017-0964-7

González-Mira A, Varó I, Solé M, Torreblanca A (2016) Drugs of environmental concern modify Solea senegalensis physiology and biochemistry in a temperature-dependent manner. Environ Sci Pollut Res 23:20937-20951. https://doi.org/10.1007/s11356-016-7293-x

Gracia-Lor E, Martínez M, Sancho J V, et al (2012) Multi-class determination of personal care products and pharmaceuticals in environmental and wastewater samples by ultra-high performance liquid-chromatographytandem mass spectrometry. Talanta 99:1011-1023. https://doi.org/10.1016/j.talanta.2012.07.091

Gutiérrez-Noya VM, Gómez-Oliván LM, Ramírez-Montero M del C, et al (2020) Ibuprofen at environmentally relevant concentrations alters embryonic development, induces teratogenesis and oxidative stress in Cyprinus carpio. Sci Total Environ 710:136327. https://doi.org/10.1016/j.scitotenv.2019.136327

Page $14 / 20$ 
Hernández F, Ibáñez M, Botero-Coy AM, et al (2015) LC-QTOF MS screening of more than 1,000 licit and illicit drugs and their metabolites in wastewater and surface waters from the area of Bogotá, Colombia. Anal Bioanal Chem 407:6405-6416. https://doi.org/10.1007/s00216-015-8796-x

Herrera-Cruz E, Aristizabal-Regino J, Yepes-Blandón J, et al (2019) Evaluation of three cryoprotectants to preserve striped catfish ( Pseudoplatystoma magdaleniatum ) semen. Rev Colomb Biotecnol XXI:55-62. https://doi.org/10.15446/rev.colomb.biote.v21n2.77847

Kasprzyk-Hordern B, Dinsdale RM, Guwy AJ (2009) The removal of pharmaceuticals, personal care products, endocrine disruptors and illicit drugs during wastewater treatment and its impact on the quality of receiving waters. Water Res 43:363-380. https://doi.org/10.1016/j.watres.2008.10.047

Kim JW, Ishibashi H, Yamauchi R, et al (2009) Acute toxicity of pharmaceutical and personal care products on freshwater crustacean (Thamnocephalus platyurus) and fish (Oryzias latipes). J Toxicol Sci 34:227-232. https://doi.org/10.2131/jts.34.227

Liu N, Jin X, Feng C, et al (2020) Ecological risk assessment of fifty pharmaceuticals and personal care products (PPCPs) in Chinese surface waters: A proposed multiple-level system. Environ Int 136:105454. https://doi.org/10.1016/j.envint.2019.105454

Mathias FT, Fockink DH, Disner GR, et al (2018) Effects of low concentrations of ibuprofen on freshwater fish Rhamdia quelen. Environ Toxicol Pharmacol 59:105-113. https://doi.org/10.1016/j.etap.2018.03.008

Mojica J, Usma J, Álvarez R, Lasso CA (2012) Libro rojo de peces dulceacuícolas de Colombia 2012. Bogotá (Colombia)

Mojica J, Valderrama M, Jimenez-Segura L, Alonso JC (2016) Pseudoplatystoma magdaleniatum. In: IUCN Red List Threat. Species. http://dx.doi.org/10.2305/IUCN.UK.2016-1.RLTS.T58439165A61474168.en

Motov S, Butt M, Masoudi A, et al (2020) Comparison of Oral Ibuprofen and Acetaminophen with Either Analgesic Alone for Pediatric Emergency Department Patients with Acute Pain. J Emerg Med 58:725-732. https://doi.org/10.1016/j.jemermed.2020.02.010

Ngo VTH, Bajaj T (2020) Ibuprofen. In: ncbi (ed) StatPearls. StatPearls Publishing

Noreña-Ramirez DA, Murillo-Perea E, Guio-Duque JA, Arteaga JJM- (2012) Heavy metals (Cd, Pb and Ni) in fish species commercially important from Magdalena river, Tolima tract, Colombia. Rev Tumbaga 2:61-76

Official Journal of the European Union (2010) Directive 2010/63/EU of the European Parliament and of The Council of 22 September 2010 on the protection of animals used for scientific purposes. L 276/33-79 $(20.10 .2010)$

Özgen Ü, Savaşan S, Buck S, Ravindranath Y (2000) Comparison of DiOC6(3) uptake and annexin V labeling for quantification of apoptosis in leukemia cells and non-malignant $\mathrm{T}$ lymphocytes from children. Commun Clin Cytom 42:74-78. https://doi.org/10.1002/(SICI)1097-0320(20000215)42:1<74::AID-CYTO11>3.0.C0;2-6 
Padmini E, Usha Rani M (2011) Mitochondrial membrane potential is a suitable candidate for assessing pollution toxicity in fish. Sci Total Environ 409:3687-3700. https://doi.org/10.1016/j.scitotenv.2011.06.020

Palacio J (2009) Biologic characteristics of blanquillo Sorubim cuspicaudus Littmann, Burr and Nass, 2000 and bagre rayado Pseudoplatystoma magdaleniatum Buitrago-Suárez and Burr, 2007 (Siluriformes: Pimelodidae) related to their reproduction in the middle basin of the Ma. Actual Biológicas 31:53-66

Parolini M (2020) Toxicity of the Non-Steroidal Anti-Inflammatory Drugs (NSAIDs) acetylsalicylic acid, paracetamol, diclofenac, ibuprofen and naproxen towards freshwater invertebrates: A review. Sci Total Environ 740:140043. https://doi.org/10.1016/j.scitotenv.2020.140043

Pemberthy D, Padilla Y, Echeverri A, Peñuela GA (2020) Monitoring pharmaceuticals and personal care products in water and fish from the Gulf of Urabá, Colombia. Heliyon 6:. https://doi.org/10.1016/j.heliyon.2020.e04215

Petrie B, Barden R, Kasprzyk Hordern B (2014) A review on emerging contaminants in wastewaters and the environment: Current knowledge, understudied areas and recommendations for future monitoring. Water Res 72:3-27

Pico Y, Belenguer V, Corcellas C, et al (2019) Contaminants of emerging concern in freshwater fish from four Spanish Rivers. Sci Total Environ 659:1186-1198. https://doi.org/10.1016/j.scitotenv.2018.12.366

Ragugnetti M, Adams ML, Guimarães ATB, et al (2011) Ibuprofen genotoxicity in aquatic environment: An experimental model using Oreochromis niloticus. Water Air Soil Pollut 218:361-364.

https://doi.org/10.1007/s11270-010-0698-0

Restrepo G, Varela E, Duque JE, et al (2019) Freezing, Vitrification, and Freeze-Drying of Equine Spermatozoa: Impact on Mitochondrial Membrane Potential, Lipid Peroxidation, and DNA Integrity. J Equine Vet Sci 72:8-15. https://doi.org/10.1016/j.jevs.2018.10.006

Ribas JLC, da Silva CA, de Andrade L, et al (2014) Effects of anti-inflammatory drugs in primary kidney cell culture of a freshwater fish. Fish Shellfish Immunol 40:296-303. https://doi.org/10.1016/j.fsi.2014.07.009

Rice E, Baird R, Eaton A (2017a) 2320 Alkalinity. In: Standard Methods for the examination of water and wastewater, 23rd edn. American Public Health Association, American Water Works Association, Water Environment Federation

Rice E, Baird R, Eaton A (2017b) 2340 Hardness. In: Standard Methods for the examination of water and wastewater, 23rd edn. American Public Health Association, American Water Works Association, Water Environment Federation

Rice E, Baird R, Eaton A (2017c) 2540 Solids. In: Standard Methods for the examination of water and wastewater, 23rd edn. American Public Health Association, American Water Works Association, Water Environment Federation

Rieger AM, Nelson KL, Konowalchuk JD, Barreda DR (2011) Modified annexin V/propidium iodide apoptosis assay for accurate assessment of cell death. J Vis Exp 3-6. https://doi.org/10.3791/2597 
Rocco L, Frenzilli G, Fusco D, et al (2010) Evaluation of zebrafish DNA integrity after exposure to pharmacological agents present in aquatic environments. Ecotoxicol Environ Saf 73:1530-1536. https://doi.org/10.1016/j.ecoenv.2010.07.032

Rojas M, Garcı LF, Puzo G, Olivier M (2000) tuberculosis - Induced Macrophage Apoptosis by Altering Ca + 2 Dependent Cell Signaling. J Infect Dis 182:240-251

Santamaría Merchán SC (2013) Nutrición y Alimentación en Peces Nativos. Universidad Nacional Abierta y a Distancia

Saravanan M, Devi KU, Malarvizhi A, Ramesh M (2012) Effects of Ibuprofen on hematological, biochemical and enzymological parameters of blood in an Indian major carp, Cirrhinus mrigala. Environ Toxicol Pharmacol 34:14-22. https://doi.org/10.1016/j.etap.2012.02.005

Sathishkumar P, Meena RAA, Palanisami T, et al (2020) Occurrence, interactive effects and ecological risk of diclofenac in environmental compartments and biota - a review. Sci Total Environ 698:134057.

https://doi.org/10.1016/j.scitotenv.2019.134057

Tejeda-Benitez L, Flegal R, Odigie K, Olivero-Verbel J (2016) Pollution by metals and toxicity assessment using Caenorhabditis elegans in sediments from the Magdalena River, Colombia. Environ Pollut 212:238-250.

https://doi.org/10.1016/j.envpol.2016.01.057

Tejeda-Benítez L, Noguera-Oviedo K, Aga DS, Olivero-Verbel J (2018) Toxicity profile of organic extracts from Magdalena River sediments. Environ Sci Pollut Res 25:1519-1532. https://doi.org/10.1007/s11356-017-0364-9

Ternjej I, Mihaljević Z, Stanković I, et al (2010) Estimation of DNA integrity in blood cells of eastern mosquitofish (Gambusia holbrooki) inhabiting an aluminium-polluted water environment: An alkaline comet assay study. Arch Environ Contam Toxicol 59:182-193. https://doi.org/10.1007/s00244-010-9469-6

White D, Lapworth DJ, Civil W, Williams P (2019) Tracking changes in the occurrence and source of pharmaceuticals within the River Thames, UK; from source to sea. Environ Pollut 249:257-266.

https://doi.org/10.1016/j.envpol.2019.03.015

Xia L, Zheng L, Zhou JL (2017) Effects of ibuprofen, diclofenac and paracetamol on hatch and motor behavior in developing zebrafish (Danio rerio). Chemosphere 182:416-425.

https://doi.org/10.1016/j.chemosphere.2017.05.054

Zapata LA, Usma JS, Rodríguez T, et al (2015) Recursos pesqueros de Colombia, principales especies, conservación y pesca responsable. AUNAP, WWF Colombia, Cali (Colombia)

Zhang K, Yuan G, Werdich AA, Zhao Y (2019) Ibuprofen and diclofenac impair the cardiovascular development of zebrafish (Danio rerio) at low concentrations. Environ Pollut 113613.

https://doi.org/10.1016/j.envpol.2019.113613

Zorova LD, Popkov VA, Plotnikov Y, et al (2018) Mitochondrial membrane potential. Anal Biochem 552:50-59. https://doi.org/10.1016/j.ab.2017.07.009 
Figures

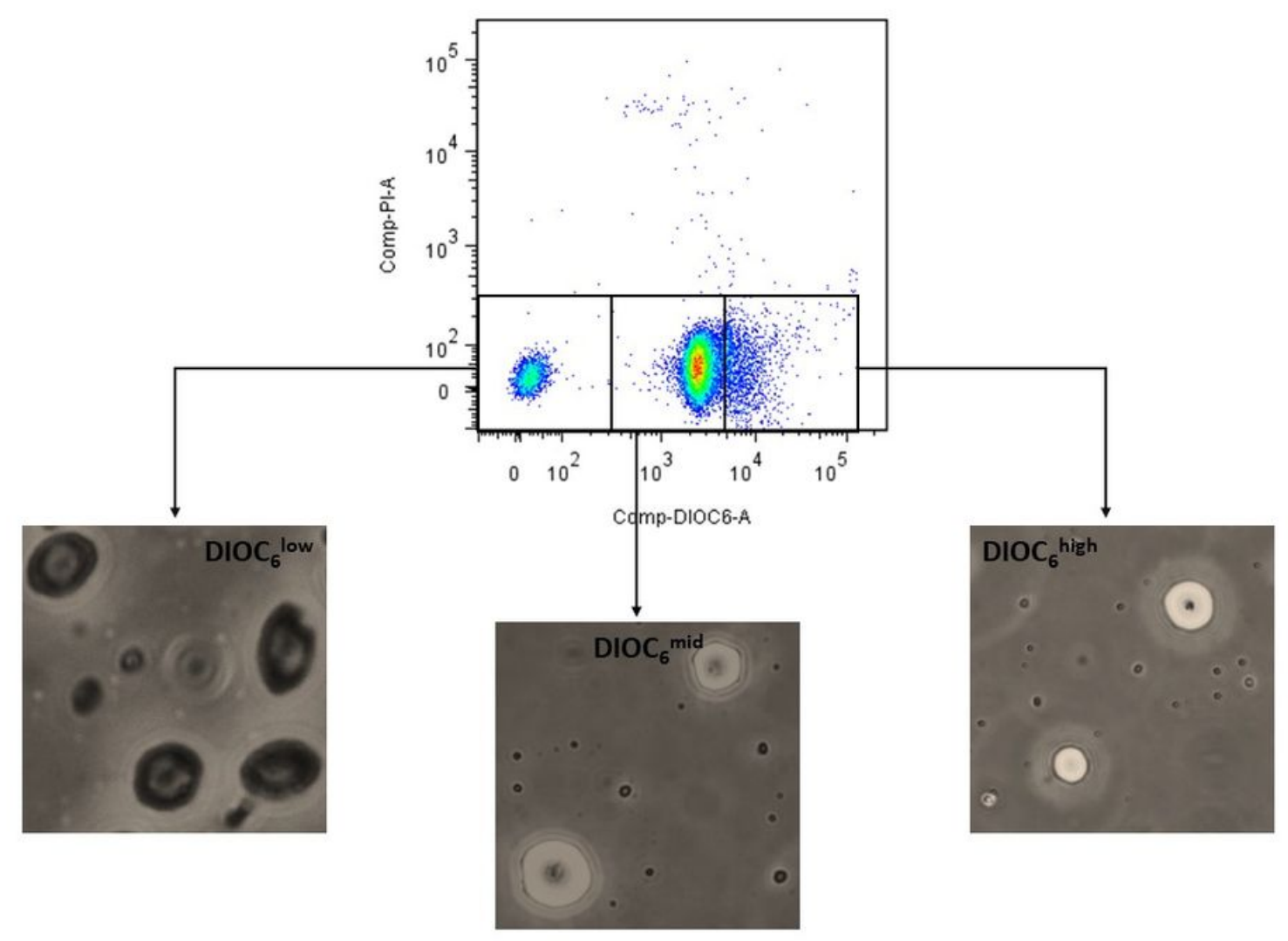

Figure 1

Cell staining with DIOC6 and PI, and separation according to the intensity of DIOC6 (low, medium, and high $\Delta \Psi \mathrm{M})$. 



\section{Figure 2}

Exclusion of aggregates, selection of single events (a). Selection of the cell population by contrast in size and granularity (b). The contrast between DiOC6-positive cells vs. propidium iodide (PI) (c), Q1: Cells with cell membrane damage, positive for PI. Q2: Cells with cell membrane damage. Q3: Viable cells with different amounts of DIOC6 uptake. Q4: Cells negative for IP and DIOC6. 



\section{Figure 3}

Exclusion of aggregates, selection of unique events (a). Selection of single cells by the contrast of PI-A vs PI-W (b). Histogram for DNA damage determination (c), <2n: DNA damage, fragmented. 2n: DNA non-fragmented. 4n: Somatic cells. 